\title{
CURRENT METHODS IN THE TREATMENT OF VENEREAL DISEASES IN FRANCE*
}

\author{
BY \\ PIERRE DUREL \\ Médecin de l'Hôpital St. Lazare, Paris
}

It is not easy to describe the present-day opinions of French specialists because the revolutionary changes in our methods produced by penicillin are far from being complete, but some of the more important aspects of the subject are outlined below.

\section{SYPHILIS}

Is syphilis a relatively mild scourge?-To attract popular attention some propagandists have made use of ridiculously exaggerated figures. For example, the total number of abortions (wrongly presumed to be almost all due to syphilis) has been added to the number of deaths certified as due to syphilis, and one then talks of $1,400,000$ deaths or abortions per annum in France as the result of syphilis. Official statistics are far from bearing this out (deaths from syphilis in France officially reported in 1949 were 1,426). As a reaction against this ridiculous attitude, Clément Simon (1948)' has described syphilis as being the most benign of chronic diseases. Some specialists have objected to this statement on the grounds that it would tend to make persons infected with syphilis careless and might make public authorities less ready to grant funds for the fight against this disease. As a matter of fact, everybody is agreed that syphilis presents a serious potential danger but one easily overcome by good treatment.

There must be a more rational definition of what constitutes congenital syphilis.-French paediatricians and obstetricians have protested against the tendency to diagnose congenital syphilis in nonluetic conditions. Debré (1949) pointed out the following facts :

(a) Abortions in the first months of pregnancy are practically never due to syphilis, for it is not until the fifth month of intra-uterine life that the treponema is able to penetrate the foetus.

\footnotetext{
* Paper read to the M.S.S.V.D. on 23 February, 1951.
}

(b) Congenital malformations due to early developmental disturbances ought not to be classed as syphilitic in origin for the same reason. The so-called "stigmata" of syphilis ought to be carefully re-examined. It used to be taught that 25 per cent. of children, in hospital and in various clinics and homes with chronic ailments, were congenital syphilitics. If one is more careful with the diagnosis, one finds congenital syphilis in only 1 per cent. of these cases. Many instances of supposed syphilitic "stigmata" can be explained as the results of trauma, or genetic factors. One therefore excludes syphilis from being the cause of the greater number of cases of hydrocephalus, infantile cerebral hemiplegia, retinitis pigmentosa, saddle-nose, etc.

(c) Children of syphilitic parents may sometimes escape infection. Lamy and others (1949) reported that the syphilitic mother of binovular twins transmitted the infection to only one foetus.

(d) The incidence of congenital syphilis in children over 10 years of age is almost nil.

For the most part, French syphilologists support these views but admit the possibility of exceptional cases where the treponema must have entered the foetus before the fifth month (Ascheim), or where the spirochaetal granule is able to do what the treponema cannot, or where parental syphilis can be found in children over 10 years of age.

The conclusion of the discussion between specialists of the two classes at the joint conference in Zurich (Congrès de Pédiatrie et Union Internationale contre le Péril Vénérien, 1950) was to the effect that children should only be treated when there are very good grounds for suspecting syphilitic infection. Apart from the typical cutaneous and visceral signs of congenital syphilis, Charpy (1950) stresses the value of radiological examination of the four limbs during the first month of life :

587 children were so examined and in 305 infants of syphilitic parents, who had been effectively treated, there was no case of osteochondritis. In seven children 
of mothers who had secondary syphilis during their pregnancy but who had been effectively treated there was no case of osteochondritis. In 97 children of syphilitic parents inadequately treated, there were 78 per cent. of cases of osteochondritis, and in 178 children unselected and without syphilis being suspected in the parents there were 5 per cent. of cases of osteochondritis.

Of course, it is realized that a serological test is only of value three months after birth, by which time the child, if infected, will have developed his own reagin.

In spite of this, the majority of syphilologists advise the treatment of a child born to parents with active syphilis even if the child shows no signs of the disease.

Treatment of Syphilis in The Adult.-In 1948, in the civil population of the U.S.A., 93,600 cases of primary or secondary syphilis were reported. The budget for that year for the fight against venereal diseases amounted to $\$ 31,350,000$ (W.H.O. 1950).* Such an incidence enabled the Americans to carry out valuable investigations which have aroused the interest of the rest of the world.

We, in France, have followed with the liveliest interest the work of Thomas and others (1950) in which it was claimed that a single injection of $2,400,000$ units of penicillin (P.A.M.) is a valuable form of treatment for early syphilis. It would be unscientific were we, from a narrow nationalistic point of view, not to take cognizance of work followed with persistence in another part of the world : indeed, it should be noted that Americans were not slow to follow the French lead in antihistaminics and the drugs used in the treatment of Parkinsonism, and we appreciate the advantages of their methods.

Nevertheless, French specialists still hesitate to arrive at a decision on such a serious matter. Patients in France readily agree to a treatment extending over four years, and we have shared the illusory hopes and disappointments of Ehrlich's therapia sterilisans magna. Were "flash treatments" later on found to be insufficient, we should have difficulty in persuading patients to accept treatments of long duration. We therefore prefer a gradual approach to the new methods.

In a recent report by Degos and others (1950) the results of the pre-penicillin era are set out. Of 2,649 patients undergoing the classical treatment with arsenic and bismuth for four years and kept under observation thereafter for periods varying from 5 to 25 years, it has been shown that the percentage rate of re-infections was only 0.38 and

* In France the figure for civilians and troops was 8,682 and the budget was one of $\mathbf{2 4 0}$ million francs. of relapses only $\mathbf{0 . 2 6}$. In other words, only 0.64 per cent. required further treatment. Of these patients, 128 underwent lumbar puncture and the only abnormality found was an increase in the albumen content of the cerebrospinal fluid in one case.

An earlier report by Sézary and Galmiche (1945) gives similar results. In 2,000 cases a negative Wassermann reaction was obtained after the first series of injections of arsenic and bismuth in 90 per cent. of primary and in 78 per cent. of secondary syphilis.

These figures are significant only if the patients completed their treatment. De Graciansky and others (1950) wished to make this point clear; of 388 syphilitics who began their treatment in 1945 and 1946, 176 were still under observation by these authors in 1950, and 132 by other workers ; eighty had been lost sight of (although it is probable that some of these had continued treatment elsewhere). Thus, by the end of the fourth year, 21 per cent. of patients had disappeared, twothirds of them ( 14 per cent.) before the end of the first year. Women are the worst offenders in this respect. Of course, the shorter and more intensive the treatment, the fewer will be the defaulters. Aiken (1949) reported that $2 \cdot 1$ per cent. of his patients in the U.S.A. had not completed an 8days' course.

The present position in France (which is doubtless a temporary one) has been arrived at for the following reasons :

(a) Fear of Arsenic.-Every one of us knows one or two tragedies associated with the use of arsenic. Since it was recognized that penicillin had the same power of rapid sterilization and cicatrization, the majority of us have gladly given up neoarsphenamines and arsenoxides. It is only considerations of cost that are responsible for arsenic still being used to some extent, since in France, arsenic is cheaper than penicillin.

(b) Confidence in the Value of Bismuth.-Bismuth therapy had its origin in France, and years of experience have shown that it fulfilled what was expected of it.

Gaté and Cuilleret (1947) have published the results of 16 years' experience, using courses of injections of liposoluble bismuth, hydroxide of bismuth, or iodobismuthate in oily suspension. The first course consists of fifteen to twenty injections, and the subsequent ones of ten or twelve. Courses were repeated every three months for four years in men and for five years in women. The results were as follows :

63 sero-negative primary cases remained sero-negative throughout. Of 177 sero-positive primary cases, 68 per cent. were negative after the first course of injections, a further 22 per cent. were negative after the second, 7 per cent. after the third, and the remaining 3 per cent. after the fourth. Of 220 secondary cases, 55 per cent. were negative after the first course of injections, a further 32 per cent. after the second, 11 per cent. after 
the third, and the remaining 2 per cent. after the fourth. Joulia (1950), in 405 cases of sero-positive primary syphilis, obtained serological reversal after a single course of injections in 83.8 per cent.; in confirmation of this one can quote figures reported by Coste and others, (1946), Fernet and Guibert (1946), and Casabianca (1947).

Here then, we have excellent serological results (in parallel with the clinical findings), and it is easily understood that French workers are unwilling to give up this powerful medicament without good cause. Further, we are well content to see those infected with syphilis, who often lead an irregular sexual life, remain continuously under the influence of bismuth. Levaditi (1928) even proposed bismuth prophylaxis of prostitutes, which is perhaps going a little too far (the experiment was tried by Sonnenberg, 1935 a, b). It should be added that, in America, Turner (1948) spoke in favour of the "chemical quarantine" that bismuth ensures. It is, perhaps, because our patients are kept so long under bismuth that they are unable to be re-infected and do not require to be re-treated.

(c) Uneasiness about Resistant Sero-Positives.American syphilologists tell us that a positive serological test is of the nature of a "scar", and that, if a technique of treatment gives good clinical results and satisfactory serological reversals in the majority of patients, it is of little importance if some cases remain sero-positive. We do know that serological tests are evidence of an imbalance which is no exact measurement of infection. It is firmly established that intensive treatment with arsenic and bismuth usually produces a negative Wassermann by the second or third month with no cases of relapse : whereas irregular or insufficient treatment often results in a persistent positive Wassermann reaction and sometimes in clinical relapse. Attaining a negative Wassermann reaction by the second or third month is of itself no guarantee against relapse, and in any case, we do not like our patients to remain sero-positive.

Opinion in the U.S.A. is not unanimous ; Grover (1948) on the subject of the cerebrospinal fluid says :

The trend of specific serological reactions of the cerebrospinal fluid always seems to be a direct indication of the degree of activity of parenchymatous involvement. Many workers have noted a direct relationship between the strongly positive Wassermann reaction and clinical relapse : and it is generally agreed that clinical cure is associated with a fall in the Wassermann titre.

(d) Awareness of the Danger of Late Manifestations of Syphilis.-We are accustomed to remember this danger, and in France reference is often made to the teaching of Fournier, who showed that the critical period was between the eighth and twelfth years after infection, in both visceral and neurosyphilis. Fournier (1873) reported a case occurring 55 and Touraine and others (1948) a case occurring 66 years after the primary chancre. It should be remembered, however, that Fournier had only mercury at his disposal. Times have changed, but the teachings of the great French master have left their mark and we are still afraid of the treachery of the treponema.
Present Practice.-For the reasons stated most French workers base their treatment on the association of penicillin and bismuth, continuing the treatment for a minimum of two years in order to benefit from what Gougerot and Degos (1950) call the "double guarantee" given by these two excellent drugs.

Penicillin.-In hospital we sometimes still use aqueous penicillin injections every 4 hours : but we tend more and more to the use of preparations which we term penicillines-retard, of which there are several varieties.

Penicillin-subtosan is a preparation which gives a satisfactory concentration for some eight hours. The antibiotic is dissolved in a 25 per cent. polyvinyl-pyrrolidone solution (P.V.P.). This P.V.P., which has a large molecule, came into use after the investigations made some years ago (Durel and Dubost, 1945) for the purpose of lengthening the action of a number of medicaments -hormones, anaesthetics, sodium salicylate, etc.

Aqua-peni-quinyl is a complex salt of penicillin suspended in a glucose solution $(300,000$ units in $4 \mathrm{ml}$.). A satisfactory concentration is obtained for over 10 hours.

Scurocilline is a mixture of penicillin $\mathrm{G}$ and penicillinprocaine (to provide both a loading dose and sustained action) and in a dosage of 300,000 units in $2 \mathrm{ml}$. gives an adzquate concentration for some $\mathbf{1 5}$ hours.

Microcrystalline Penicillin-procaine suspended in oil with 2 per cent. of aluminium monostearate or in water $(300,000$ units in $1 \mathrm{cc}$.) is now preferred to the preparations previously mentioned.

Bipenicillin, penicillin-procaine enhanced by ordinary penicillin $\mathrm{G}(500,000$ units in $2 \mathrm{ml}$.), is also often used.

We also make use of oral penicillin tablets containing 200,000 units with an alkaline excipient. Sometimes for oral use we prescribe penicillin G in the following solution, made just before administration :

$\begin{array}{lr}\text { Trisodium citrate } & 1 \mathrm{~g} . \\ \text { Bitter orange syrup } & 2 \mathrm{~g} . \\ \text { Water } & 50 \mathrm{ml} .\end{array}$

The possibility of the abuse by patients of oral penicillin therapy is obvious, and in 1950 the Academy of Medicine, on the suggestion of Prof. Gougerot, decided that oral penicillin preparations should be sold only on medical prescription.

Bismuth.-The water-soluble salts of bismuth are no longer used. We, for the most part, favour lipo-soluble preparations : bismuth carboxythylmethyl-monostearate containing the equivalent of $80 \mathrm{mg}$. bismuth metal in $2 \mathrm{ml}$. (Bivatol), or bismuth butyl-thiolaurate dissolved in ethyl oleate containing $75 \mathrm{mg}$. bismuth metal in $1.5 \mathrm{ml}$. (Bispecia). We like 
these lipo-soluble preparations because they appear to be a "happy medium" between the watersoluble salts which are too rapidly metabolized and the insoluble salts which sometimes remain too long in the body.

Nevertheless, towards the end of a course of injections or towards the end of a patient's treatment we are accustomed to use an oily suspension of insoluble bismuth salts such as bismuth hydroxide (130 mg. bismuth metal in $2 \mathrm{ml}$.) or iodobismuthate of quinine ( $75 \mathrm{mg}$. bismuth metal in $3 \mathrm{ml}$.). Courses consist of twelve to fifteen injections at the rate of two (or sometimes three) injections a week.

STANDARd Treatment of Cases of EARLy Syphilis. - The following is one of the most often used routines :

Days 1 to $10 \quad \ldots \quad 600,000$ units of penicillin-retard (two injections of Scurocilline or one injection of $2 \mathrm{ml}$. procaine penicillin daily).

Days 1 to 40 .. One injection twice weekly of lipo-soluble bismuth.

Three weeks rest and, then, a series of courses of twelve bismuth injections given every three months for two to four years.

Although serological reversal is quicker in seropositive primary than in fully developed secondary syphilis we give the same treatment. If there is a likelihood of a Herxheimer reaction (as in mutilating chancre or in widely generalized secondary syphilis) we are in the habit of preceding the use of penicillin by one injection daily for 3 days of cyanamide of mercury. Throughout the course of treatment serological tests are carried out regularly. It is common to make use of the quantitative reactions, the practice having perhaps originated in France with the work of Vernes (1918). The tests most commonly used are Hecht, Debains, Kahn-standard and Kline. The Meinicke reaction is less and less used. We are obliged by law to use one flocculation and two precipitation tests in each serum examination. Cardio-lipidin antigen has only just begun to be made in France; but thanks to the kindness of Dr. Charles Rein we have now been using this American-made antigen for several months at the St. Lazare Hospital with complete satisfaction.

With the treatment described it is unusual for a case to be still sero-positive after 120 days. Nevertheless, in every case we continue treatment for 2 to 4 years even when the Wassermann reaction is negative.

When treatment has been completed, patients are advised to remain under serological observation, and prostitutes are compelled by law to do so.

We believe that lumbar puncture seldom tells us anything when patients are clinically and sero- logically negative and lumbar puncture is practised only in special cases.

I have described the method of treatment most commonly adopted in France at the present time, but experiments are also being made with other methods.

\section{Less Usual Techniques}

(1) Treatment by Penicillin Alone.-It is understandable that every venereologist has attempted to form his own opinion of what is the best dosage of penicillin, having regard to the amount of penicillin given and the length of time over which treatment is carried out. Gougerot and others (1948), Gaté and Pellerat (1949), Degos and Garnier (1949), and Bureau and others (1949), hold the view that the length of treatment matters less than the amount of penicillin given. An injection of aqueous penicillin even in high dosage does not act on the treponema long enough, whereas small doses of penicillin repeated or given in the form of penicillin-retard ensure adequate levels. Bolgert, Lévy, and their co-workers (1947-19491950-1951) report on a series of 138 cases. It will be noted that the treatment is not exclusively with penicillin, for these workers attach great importance to beginning with mercury and continuing with penicillin for a good many days.

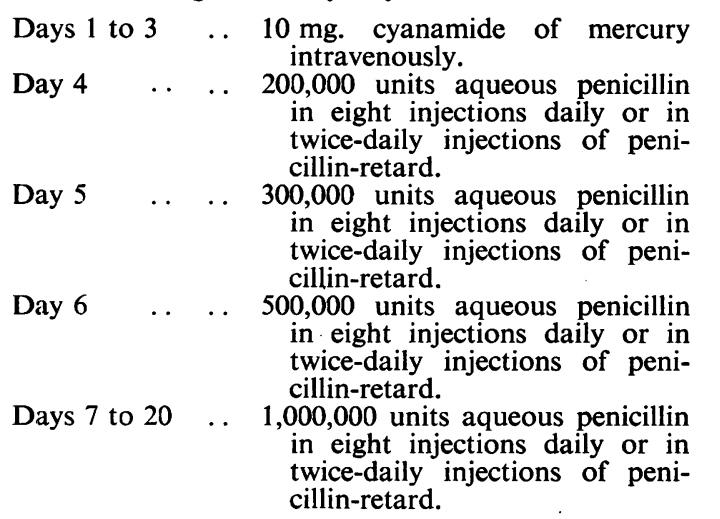

The effect upon the lesions is what is to be expected from every form of active treatment.

Serological investigations were carried out using seven blood tests, and no case was regarded as negative unless shown to be so by all tests. Although sera remaining positive after 6 months are reported as resistant, Bolgert and Lévy think this of little significance, as they observed a patient in whom serological reversal began only during the eighth month of observation (and who had two negative reports on the cerebrospinal fluid), and in their view, in the absence of clinical symptoms, one should not think of resuming treatment until 
after serological reactions have remained positive for 12 months.

The serological results are summarized below. Patients were kept under observation for periods varying from 3 months to 3 years. Sixteen patients remained under observation for only 3 months, and fifteen of them were sero-negative when last seen.

24 sero-negative
primary

primary .. Remained negative with the exception of three cases, all regarded as re-infections occurring 68,83 , and 85 days after beginning treatment.

46 sero-positive primary secondary ..

All negative in less than 6 months.

64 became negative and remained so in less than 6 months, with the exception of four which were regarded as re-infections. Three cases were sero-positive at the end of 6 months, but one of these began to alter during the 8 th month. One relapsed.

47 lumbar

punctures .. All normal, except one case, a woman who showed a slight increase in cells but who had suffered from a head injury.

9 pregnant women

. Thirteen children, all clinically healthy, twelve of whom were sero-negative. One case seropositive at birth had a mother who was sero-positive at delivery.

Seven of those 138 cases later showed clinical evidence of active syphilis : two cases were reported by Durel and Daguet (1949a) and Périn and Senghor (1949), and five by Bolgert, Lévy, and others (1950a). It seems reasonable to regard these cases as reinfections.

(2) Techniques using Penicillin and Bismuth.I would draw attention to two matters :

(a) The technique of intensive treatment.

(b) The investigation of the possible inhibitory action of one drug on the other.

(a) I believe that it was in France that it was first shown that penicillin reduces the toxicity of bismuth, and particularly that it prevents stomatitis (Touraine and others, 1947). This has allowed us to give intensive bismuth therapy on a scale until then impossible.

Touraine and his colleagues (1947 and 1948), in a series of 326 cases, studied the action of arsenic, penicillin, and bismuth, or mercury, penicillin, and bismuth, and it is the latter which has been preferred. The technique is as follows :

Days 1 to 12 .. Daily intravenous injections of

(a) 10 or $20 \mathrm{mg}$. cyanamide of mercury.

(b) 400,000 units of penicillin spread over eight injections.

Concurrent daily injections of $80 \mathrm{mg}$. lipo-soluble bismuth.

Days 15, 18, and 21 One injection of bismuth.
A slightly modified course spread over 25 days is shown diagrammatically in Fig 1.

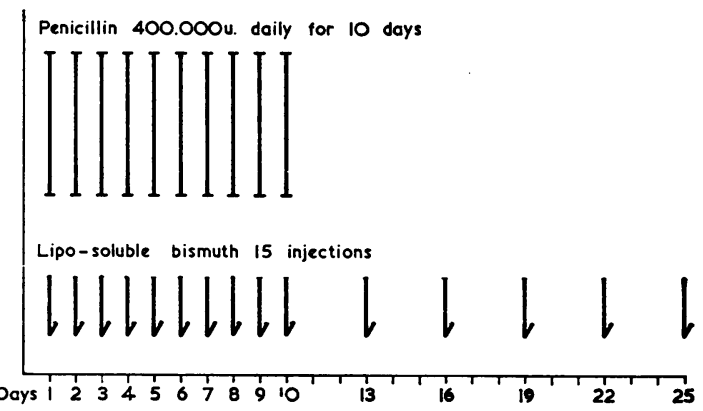

FIG. 1.-Usual intensive treatment with penicillin and bismuth in the same course.

Although Touraine in reporting his results calculates them from the day on which the last injection of penicillin was given, they are calculated in the list below from the first day of treatment in order to make a fair comparison with the other results already given. The cases treated with mercury, penicillin, and bismuth included 44 chancre, nine primo-secondary, eighty secondary, and eighteen untreated sero-positive cases, and the results were as follows :

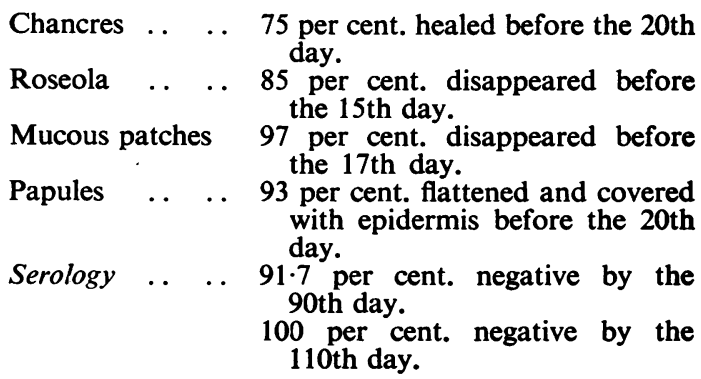

Serological reversal is quicker in early cases. In others the serological improvement is more rapid when the dose of penicillin is increased to $1,000,000$ units a day.

Touraine and others (1947c) saw two cases of clinical syphilis, apparently re-infected, one in the $3 \mathrm{rd}$ and the other in the 9th month after treatment.

This technique, which is always well tolerated, is useful in cases where one wants to give the maximum treatment in a short time. I use it in my St. Lazare clinic for prostitutes, as it is obviously suited to the case of those women who have many and varied contacts. In fact, I make use of a modification of this technique (Fig. 2) suggested to me by these facts :

(i) the first four or five daily injections of bismuth are usually well tolerated without the use of penicillin, and

(ii) it is not uncommon with Touraine's technique to see cases of stomatitis occurring after treatment is completed, because the protective action of penicillin has ceased whereas the toxic bismuth is only relatively slowly eliminated. 
I therefore prescribe a staggered treatment as follows :

Day 1 . . . 300,000 or 400,000 units penicillinretard to ensure disappearance of superficial treponemata and one injection of $75 \mathrm{mg}$. liposoluble bismuth.

Days 2 to 5 .. One daily injection lipo-soluble bismuth.

Days 6 to 12 .. One daily injection bismuth and one injection of 300,000 or 400,000 units penicillin-retard.

Days 13 to 15 .. One injection penicillin to cover the risk of the slow bismuth excretion.

Total .. . 4 4,800,000 or $6,400,000$ units penicillin plus $900 \mathrm{mg}$. lipo-soluble bismuth.

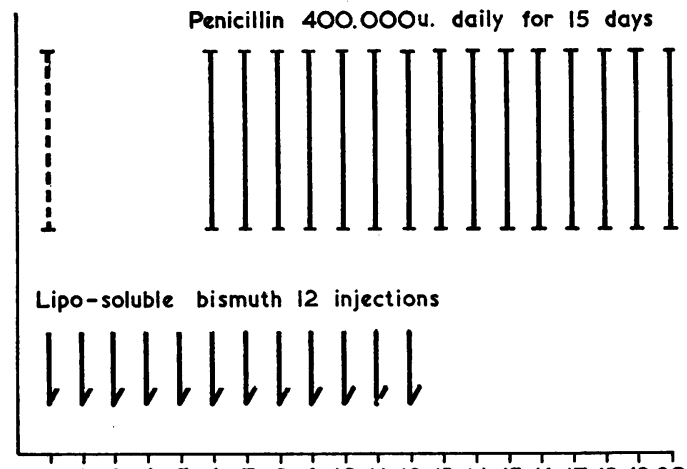

Days I $2 \begin{array}{llllllllllllllllll} & 3 & 4 & 5 & 6 & 7 & 8 & 9 & 10 & 11 & 12 & 13 & 14 & 15 & 16 & 17 & 18 & 1920\end{array}$

FIG. 2.-Staggered treatment with bismuth and penicillin (the first injection of penicillin is given only to ambulant patients).

Clinical and serological results are most satisfactory. (Durel, Rayroux, Siboulet, and Daguet, 1949).

(b) This combined treatment, penicillin and bismuth, whether hyperintensive or not, has come under criticism.

(i) Fears have been expressed about possible kidney damage from bismuth. During and shortly after the end of treatment we have found no sign of kidney damage if lipo-soluble bismuth has been used (Durel, Rayroux, Siboulet, and Daguet, 1948). On the other hand, Pellerat and Cotte (1948) have noticed transient signs, and Coste and others (1948) found some evidence of impaired renal function during the 2 nd or 3 rd month when insoluble bismuth products had been used.

(ii) Of much greater importance is the suggestion that an association of penicillin and bismuth is less active than treatment with either drug alone. It was Degos who first sounded the alarm from his clinical observations along with Lortat-Jacob and Maury (1947) in a series of 27 patients who received daily for 20 days 320,000 units amorphous penicillin and $75 \mathrm{mg}$. liposoluble bismuth (that is a total of $6,400,000$ units penicillin and $1.5 \mathrm{~g}$. bismuth). He believed that with the combined treatment symptomatic improvement was not more:'rapid and seemed to be even slower than in the case of patients treated by one or other of the medica- ments alone (injections being given in the case of bismuth three times a week). The serological reactions also seemed to tend to differ, as the following statistics show :

Chancres $\quad \ldots$ Of seventeen cases on penicillin and bismuth, 63 per cent. were sero-negative on the 80th day. Of nineteen cases on bismuth alone, 100 per cent. were seronegative on the 80th day.

Secondary syphilis of ten cases on penicillin and bismuth, 70 per cent. were sero-negative on the 80th day. Of fifteen cases on bismuth alone, 100 per cent. were seronegative on the 80th day.

American statistics (Moore, 1948) show no difference between cases receiving penicillin alone and those receiving a mixed treatment. Later reports (Plotke and others, 1950) conclude from a study of 198 cases that arsenic and bismuth enhance the action of the antibiotics.

Laboratory studies were undertaken with the object of determining the nature of the interaction of the two drugs. Levaditi and Vaisman $(1946,1950)$ and Kolmer and Rule $(1947,1948)$ have shown in rabbit syphilis a synergistic effect from the association of penicillin and bismuth. We asked Dr. Cosar (Durel, Rayroux, Siboulet, and Daguet, 1949) to investigate the possible inhibiting action of bismuth upon penicillin in experimental pneumonia in mice, and no such action was noted.

On the other hand, it may be asked if penicillin may not have an effect upon bismuth metabolism. Huriez and Desurmont (1947) believed that the excretion rate of bismuth was increased by the action of penicillin, and this view was shared by Merklen and Baudu (1948) who made observations on five patients.

During daily bismuth therapy (lipo-soluble bismuth $75 \mathrm{mg}$.), urinary excretion has reached a level of 8-10 mg. per litre by the 2 nd or 3 rd day. If on the 5th day 100,000 units of penicillin are injected, the next day the urinary output of bismuth reaches 10 to $15 \mathrm{mg}$., which seems to indicate that the penicillin had hastened bismuth clearance. Of course, renal excretion is only one aspect of metabolism and there is no evidence to show whether increase of bismuth excretion is therapeutically favourable or unfavourable.

Later studies of Huriez and his colleagues (1949, 1950 a, b) are more valuable because they deal with blood levels. When bismuth was given twice weekly it was found that the bismuth content of the blood was 5 to 6 mg. per litre after the 3rd or 4th injection, and that this figure remained constant throughout treatment, four weeks being required after completion of treatment before the complete disappearance of the metal. When penicillin was injected in the course of bismuth treatment the blood level was not modified but the rate of excretion in the urine was increased. Bismuth stored in the viscera was mobilized by the antibiotic, and at the end of this mixed treatment the bismuth disappeared from the blood in two weeks instead of four.

It is difficult to arrive at a definite conclusion regarding the advisability of giving penicillin and 
bismuth concurrently. This technique has lost ground in France and is now reserved mainly for patients whom one expects to default from treatment. In other cases the rule is penicillin first and bismuth afterwards.

(3) Other Methods less commonly Used.-The investigations with penicillin, arsenic, and bismuth of Merklen and Nezelof (1947) and Huriez and Desurmont (1947) were only steps towards techniques from which arsenic is excluded.

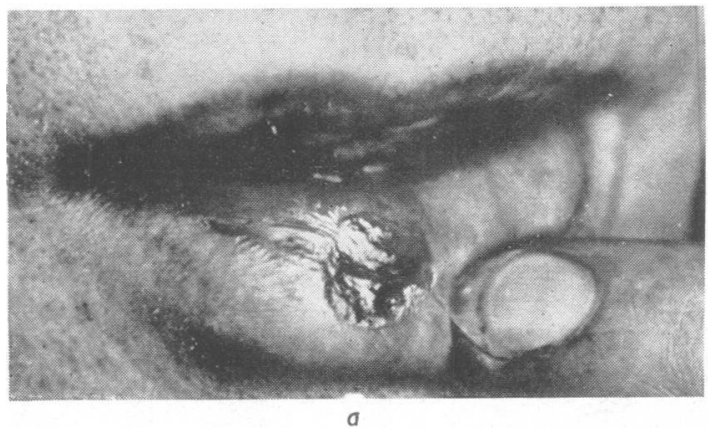

In neurosyphilis French workers use large doses of penicillin, but they generally associate this with older methods of treatment. Baudoin and Lereboullet (1950), for example, recommend in general paralysis the following course :

Cyanamide of mercury $10 \mathrm{mg}$. daily for 5 days. Penicillin 1,000,000 units daily for 10 to 15 days.

Six to ten malarial rigors.

Thereafter treatment is continued with sodium acetarsone and bismuth.

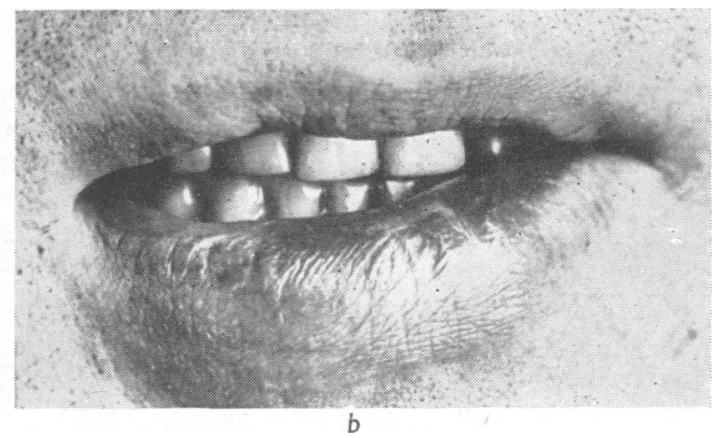

Fig. 3. - Chancre of the lip (a) one day before and $(b)$ two days after 10 days of oral penicillin. $(2,000,000 \mathrm{u}$. daily.)

I have myself by way of experiment treated nine patients with tablets of oral penicillin in place of intramuscular injections (1950b). Treatment was given for 10 days in a total daily dosage of $2,000,000$ units given in five individual doses between meals. This gives results comparable to those obtained with a daily intramuscular injection of 600,000 units. Treponemata disappeared during the first 24 hours, and the healing of lesions and serological changes were just as rapid (Fig. 3).

Herxheimer's reaction was noted early in the treatment of four of these nine patients, and there was one case of cheilitis with ano-proctitis, which is often found with oral antibiotic treatment.

One rather special form of treatment which is worth mentioning is that employed in cardiovascular syphilis, where Degos (1943) is satisfied with daily injections of $10 \mathrm{mg}$. cyanamide of mercury continued for 150 to 200 days.

(4) Indications other than Early Adult Syphilis.In congenital syphilis in the early stages paediatricians in France, as elsewhere, use large doses of penicillin, but they start cautiously in order to avoid possibly fatal reactions. Lamy (1950) advises that one should begin treatment by calculating the number of units of penicillin per $\mathrm{kg}$. body weight, giving small doses to begin with ( 3 units $/ \mathrm{kg}$.) and gradually increasing until the daily dose is 300,000 units per $\mathrm{kg}$. administered for 20 days.
Some doubt the necessity for malaria therapy, in which I think they agree with the opinion of Purdon Martin (1948).

Intrathecal penicillin has often been found effective but some fatalities were reported (in France by Schwob and others, 1948), and it has now been practically discarded.

Merklen and others (1950) reported a case of interstitial keratitis which was only slightly improved by a total of $32,000,000$ units of penicillin and several courses of injections of cyanamide of mercury, bismuth, and arsenic, and in which the condition became worse when penicillin was stopped. A subconjunctival placental graft gave an almost miraculous result.

It is, of course, the absence of any positive proof of cure which causes the difficulty in determining the best method of treatment. Vaisman (1949) studied the question by investigating the virulence of sternal marrow. After intensive treatment the marrow ceases to be virulent for mice and rabbits. Hoping that the "treponema immobilization test" would be of interest as a guide to treatment we asked our colleague, Dr. A. Sausse, to go for instruction to Dr. R. A. Nelson, and in our clinic we now use this test regularly (Durel, Sausse, Collart, Roiron, and Borel, 1951). We are thus able to confirm, for the most part, the findings of Nelson and his associates $(1949,1950)$ and those of Magnuson and Thompson (1949). The test 
is of value both in solving frequent problems of serology and in following the evolution of the disease in response to treatment. Nelson and Mayer's survival medium allows us to make a treponema suspension for various purposes. As little as 0.0025 units per ml. penicillin (Magnuson and Thompson, 1949) is sufficient to immobilize 50 per cent. of treponemata. In our laboratory, Sausse demonstrated that 0.001 units per ml. immobilizes 90 per cent. of treponemata in 18 hours, and 0.03 units per ml., 100 per cent. With arsenic the immobilization was complete with $1 \gamma$ per $\mathrm{ml}$. While at Baltimore, Sausse tried to discover if bismuth at a blood level corresponding to that with our dosage interfered with the test. He found that this does not occur until the bismuth blood content reaches $10 \mathrm{mg}$. per litre, a rate which is very seldom attained, as in the test the blood is diluted at least ten times. This observation has some value in interpreting the test in countries where bismuth treatment is continued for long periods, for we often have to make use of the Nelson test in solving problems in patients who are under treatment with bismuth. It should be noted that chloramphenicol, although active in syphilis, does not immobilize the treponemata even in high concentrations. It seems probable that the mechanism of action of antisyphilitic drugs is not the same in every case. In carrying out the Nelson test we use the Nichol's strain intended for rapid development of acute orchitis and we employ the qualitative and quantitative technique.

\section{Chancroid and Lymphogranuloma Inguinale}

There is little to say about these diseases which have practically disappeared from France (in 1949, 262 chancroids and 22 cases of Nicolas-Favre disease were reported). In these conditions sulphonamides and aureomycin give the best results, except in the chronic rectal forms of lymphogranuloma, in which treatment only reduces the purulent discharge. These views agree with those of workers elsewhere, including Willcox (1949).

\section{GONORRHOEA}

From a practical point of view, and, above all, from a teaching point of view, I believe that we must distinguish between gonococcal and nongonococcal urethritis.

\section{Gonococcal Urethritis}

As the treatment of acute male gonorrhoea presents no difficulties, French venereologists often say that the eradication of male gonorrhoea depends on the treatment of gonorrhoea in the female. Female gonorrhoea is not discovered at the same stage as gonorrhoea in the male, and when the woman comes for examination, diagnosis and treatment are often difficult. In my teaching, I often make use of the diagram shown in Fig 4, which illustrates the three stages of gonorrhoea.

First Stage.-In the beginning, gonococcal infection is associated with pus formation: acute urethritis in male and female, proctitis, acute salpingitis, arthritis, etc. Confining our attention for the moment to genital infection, it is at this stage that the man comes for advice because his urethra is painful. Both in male and female, the treatment, like the disease itself, may be extensive, and accordingly antibiotics or continued irrigations are indicated.

Second Stage.-The disease tends to become localized, and it is often here that the woman has her first examination, for she does not suffer much from the presence of the gonococcus. From localized foci, the infection can spread and cause further attacks of urethritis and prostatic involvement in the male. In the female, recurrent urethritis may occur as the result of skenitis, and purulent cervicitis may be associated with a bartholinitis or a salpingitis. The significance of such urethritis may be quite different from that of the first infection. The disease has two aspects - a visible one with obvious suppuration, and a hidden one with a localized focus. Two treatments are required, the first as for the first period, and the second to lay open or destroy the hiding place of the gonococcus. This second form of treatment is easy only when the lesion is visible (as in a malformation of the meatus or bartholinitis). In other cases, there are two possible techniques, by endoscopy or by massage which empties the focus blindly. Because of its position a tubal focus presents special problems.

Third Stage.-When the infection becomes chronic, blockage of the ducts can occur. In the female this occurs frequently and often early, for the lumen is narrow and not subject to cleansing by the passage of fluids. Such blockage in the male is rare. The treatment is to employ electrolysis or to restore patency, as may be possible, using a Benique's sound for the urethra and insufflations and penicillin-iodized oil for the tube.

(1) Acute Gonorrhoea in the Male.-In our specialist practice, of course, we begin treatment only after making bacteriological tests. General practitioners seldom do this, and I try to convince them that, even with an obvious purulent discharge, it is wise to take a smear (if only for record purposes) which can be examined afterwards and may be of value where treatment has been unsuccessful. Far too many patients receive penicillin treatment for a subacute urethritis which has been regarded as gonococcal, whereas in fact the infection was an abacterial urethritis of Waelsch ; and in such cases the diagnosis is doubtful when smears are not taken before treatment is begun.

Nowadays, in France the treatment given is generally depot-penicillin without any local treat- 


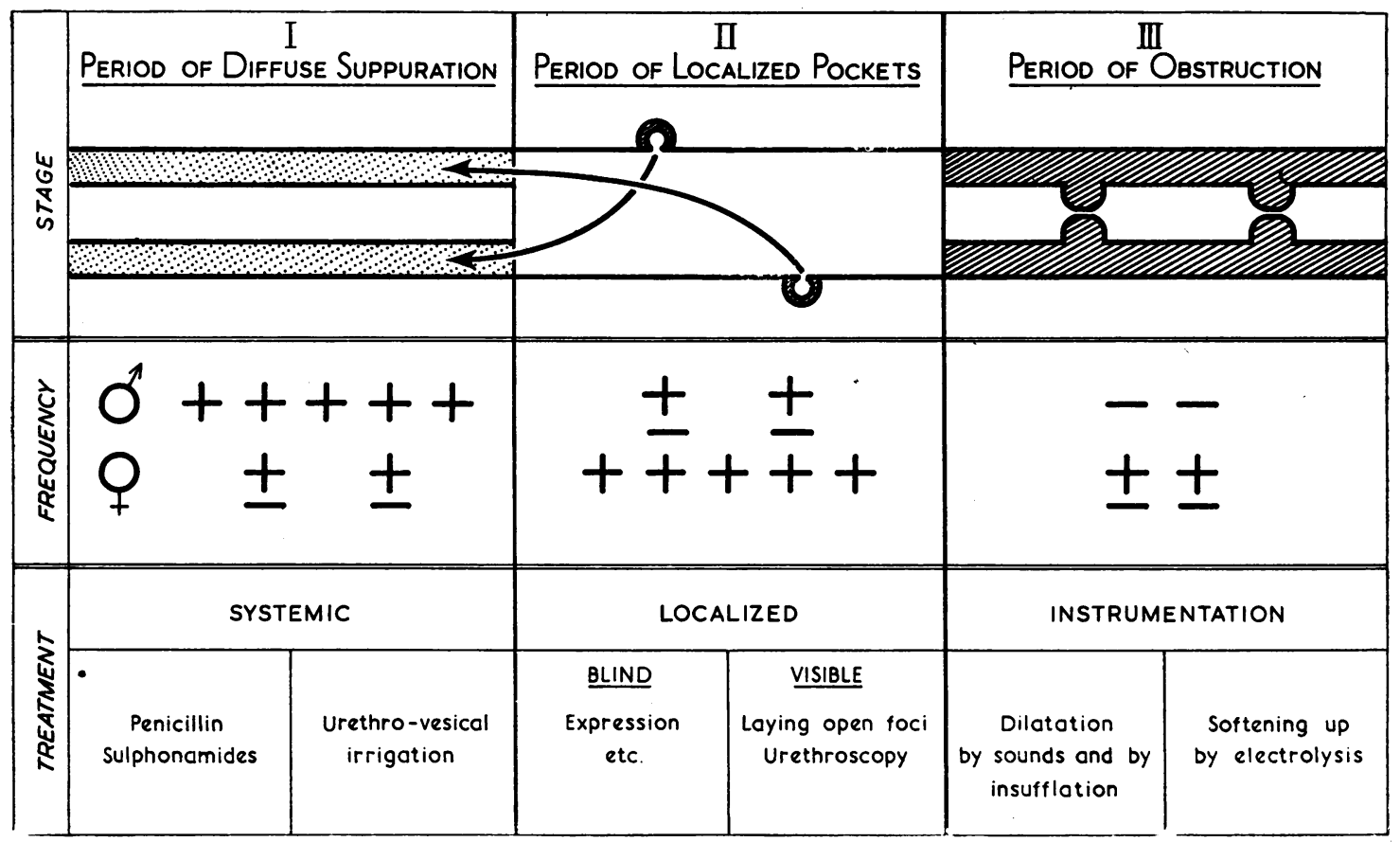

FIG. 4.-Three stages of gonorrhos incidence in male and female, and treatment.

ment. We consider effective either two injections of Scurocillin, each of 200,000 units given with an interval of 8 hours, or one injection of Aquapeni-quinyl 300,000 units, one injection of procaine-penicillin 300,000 units, or the ingestion of $1,000,000$ units (one tablet of 200,000 units every 3 hours). We regard these as minimal doses. Where possible we give a supplementary injection in the hope of preventing the development of penicillin resistance. We gladly endorse the prudent views expressed by Horne (1950) about the use of oral penicillin.

It should be understood that a blood test for syphilis is carried out 6 weeks and 3 months after the completion of treatment. Thanks to the Social Service, it is seldom that patients do not come for this examination, which also allows the cure of the gonorrhoea to be checked.

In my clinic, I also carry out a blood test at the first visit, even if the patient is not to be treated by penicillin. Gonorrhoeal patients often run numerous risks of infection, and it is wise to determine whether or not they have had a previous syphilitic infection. Thanks to this test we have discovered unsuspected sero-positive cases (Durel and Daguet, $1949 \mathrm{a}, \mathrm{b}$ ) in 2 per cent. of our private patients (many of them from North Africa).

In France streptomycin is taking the place of penicillin in the treatment of gonorrhoea. It appears to us that with streptomycin post-therapeutic discharges are rarer, and it is possible to dispense with blood tests. The usual dose of di-hydrostreptomycin is $0.50 \mathrm{~g}$.: but whenever possible I inject a similar dose 8 hours later.

Aureomycin and terramycin are still more active in dealing with associated organisms. I usually give $2 \mathrm{~g}$. aureomycin in the course of 24 hours. Unfortunately, this treatment is very expensive $(1,500$ fr. for 2 g.), but the Social Security repays 80 per cent. of the price. I have had no personal experience of chloramphenicol which is not much used in France for the treatment of gonorrhoea.

Sulphonamides are also credited with reducing the incidence of post-penicillin discharge. For example, in addition to penicillin, $4 \mathrm{~g}$ sulphathiazole or sulphadiazine are given in 3 or 4 days. In working with Mlle Rayroux we noted that di-methylsulphadiazine, although it gives a higher concentration in the blood than the non-methylated product, is less effective in gonorrhoea. This proves that the nature of the molecule is important, a fact forgotten by those who prescribe indiscriminately any sulphonamide for the treatment of gonorrhoea.

The results of antibiotic treatment in France are the same as elsewhere. At least 90 per cent. of cases are cured after a single treatment. The important question is that of subsequent observation. Perhaps we are still somewhat obsessed by 
our memories of the eras of irrigations and of sulphonamide resistance ; and this doubtless explains our efforts to keep patients under observation and to carry out tests of cure, efforts which perhaps are unnecessary. I believe that if relapse is going to take place it happens within 15 days. I consider it better for the Social Service to take active steps to bring in the consort for treatment (in accordance with the rule, gonorrhoea is contracted and cured two by two), than to harass patients for several weeks in order to carry out tests of cure. However, our present practice is as follows : $\begin{array}{cccc}\text { Day } 1 & \ldots & \ldots & \begin{array}{c}\text { Slide-examination of the glans. } \\ \text { Streptomycin } 0.5 \mathrm{~g} \text {. morning } \\ \text { and evening. }\end{array} \\ \text { Day } 8 & \ldots & \ldots & \text { Test of cure: }\end{array}$

(i) if meatus dry : three provocative injections 0.5 per cent. silver nitrate in the course of the week, or administration of beer or other alcoholic drink.

(ii) if slight discharge, wait for a week.

Day $15 \ldots \quad$.. $\quad$ (i) Presume a cure if meatus still dry.

(ii) If meatus now dry give provocative treatment.

(iii) If discharge still persists, take cultures for $\mathbf{L}$ organisms with a view to giving aureomycin.

I am no longer convinced of the usefulness of provocative treatment with silver nitrate, and am inclined to agree with the observation of Pätiälä (1946) who noted no difference between the rate of relapse in patients to whom provocative treatment had been given and in those not receiving it. In my view, in the case of men, the best provocative test is alcohol (beer, wine, or spirits).

With a return of gonococcal discharge our practice is the same as elsewhere. We try to find a focus of infection in order to apply local treatment and we give a further course of antibiotic, possibly changing to another drug and giving a higher dosage. We have not ourselves seen any example of true antibiotic resistance in acute cases.

(2) Relapsing Gonorrhoea in the Male.-When a gonorrhoeal discharge reappears and the patient denies exposure with another partner, we insist on carrying out an examination :
(a) of the partner
(b) of the male urethra.

In France, as elsewhere, treatment consists of symptomatic cure with antibiotics, urethroscopy, and destruction of the local focus either directly or through urethroscope tube or by means of urethro-prostato-vesicular massage.

(3) Complications.-In a short paper it is impossible to describe in detail the methods of treatment of the various local manifestations of gonococcal infection in use in France. They must be very much the same as those in England. Let us record, however, that :

(1) in resistant cases of prostatitis, Darget and others (1947) inject locally a solution of penicillin (40,000 units) through the perineum or rectum.

(2) Bilger and others (1938) speak highly of infiltration with procaine to reduce the inflammation of epididymitis.

(4) Gonorrhoea in the Young Female.-In young girls, our experience in France resembles that in other countries. Diagnosis is often wrong; the dosages of antibiotics should be large; several antibiotics may be given concurrently ; local treatment is important ; the results depend largely on the intelligence with which the relatives carry out the treatment.

(5) Acute Gonorrhoea in the Female.-There is not much to be said on this subject either, as the treatment resembles that already described for acute urethritis in the male, but observation, particularly during menstruation, is necessary for two or three months.

(6) Localized Chronic Gonorrhoea in the Female. - There is more to be said on this subject. We are accustomed to talk of the disease as a bacterial infection, whether it is an infection of the cervix or of the urethra, and to emphasize the fact that these two commonly affected sites are in constant risk of being re-infected by gonococci either from below (Skene's ducts or the restum) or from above (the tubes).

I think it wise on the first visit to make a complete examination (not forgetting to make the urethra gape in order to discover skenitis, and to explore Douglas's pouch in order not to overlook salpingitis in a case of prolapse). We do not regard smears as of much importance, for cultures give us 20 per cent. more positives. This is in agreement, I believe, with the observations made in England by Wilkinson (1949), and by Cooper and others (1950). We make cultures on aluminium Petri dishes, as in the Serum Institute at Copenhagen. For rectal discharges we use the three-dilution method of Hagermann of Stockholm. We have already detected prostitutes taking penicillin tablets the day before cultures were to be made : and as the dosage was not sufficient this might be a real danger. It is a pity there is no means of quickly recognizing whether antibiotics have been taken, as may be done with the sulphonamides using the technique of Vanhaecke (1944). We agree with Demanche and others (1941) and Maupin and Lestrade (1950) that the complement-fixation test 
is unreliable for detecting the presence of gonococci in recent infections. In long-standing gonococcal infections, on the other hand, the test is of value.

The basis of treatment is, of course, the antibiotics, particularly streptomycin or aureomycin : but the relative frequency of relapse from localized foci has caused most French workers to combine antibiotics with local treatment, the latter being undertaken on the occasion of the first or second examination. Our methods (except in salpingitis, which cannot be dealt with here) may be summarized as follows :

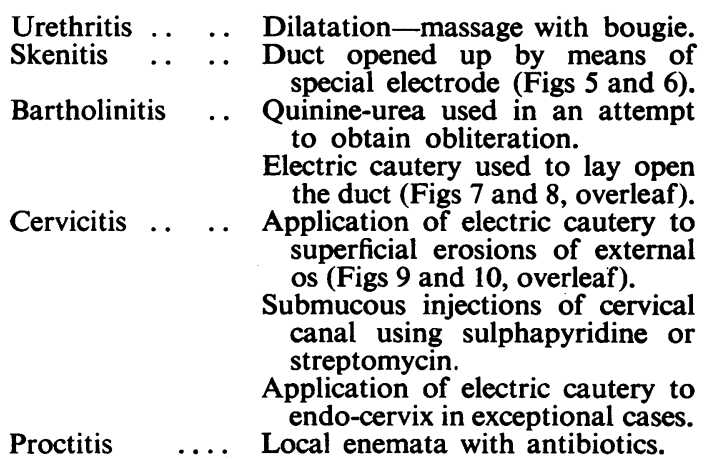

Like everyone else we are careful in our use of the term "cure." It seems to us that the follow-up should consist of repeated cultures, particularly postmenstrual, for several months. We have often had unfortunate surprises, for example three negative cultures followed by a fourth one that was positive. We agree with Berthoud (1939) that it is sometimes useful to try provocative methods, applying on a cotton-wool pledget, on the day before the cultures are made, a solution of 1 per cent. silver nitrate to the urethra and 5 per cent. to the cervix. In the case of relapse we check possible local foci of infection and resume general treatment with antibiotics and possibly protein shock. Repeated relapse suggests an associated salpingitis, or pregnancy : and these do not make the treatment any easier.

Our experience of the frequency of proctitis is not the same as that of Nicol (1948), perhaps because we have paid insufficient attention to this subject.

My last remark on the subject of gonorrhoea is that in France we have not carried out experiments in penicillin-prophylaxis. Our view is that it is not justifiable except in special cases, our fear being the possibility of inducing penicillin resistance.

\section{Non-Gonococcal Urethritis}

I have some hesitation in attempting to discuss non-gonococcal urethritis in Great Britain, where Harkness (1950) published the book to which we

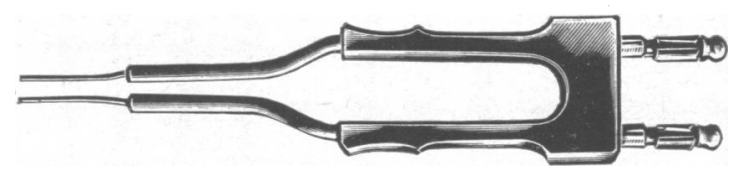

Fig. 5.-Electrode to lay open Skene's gland.

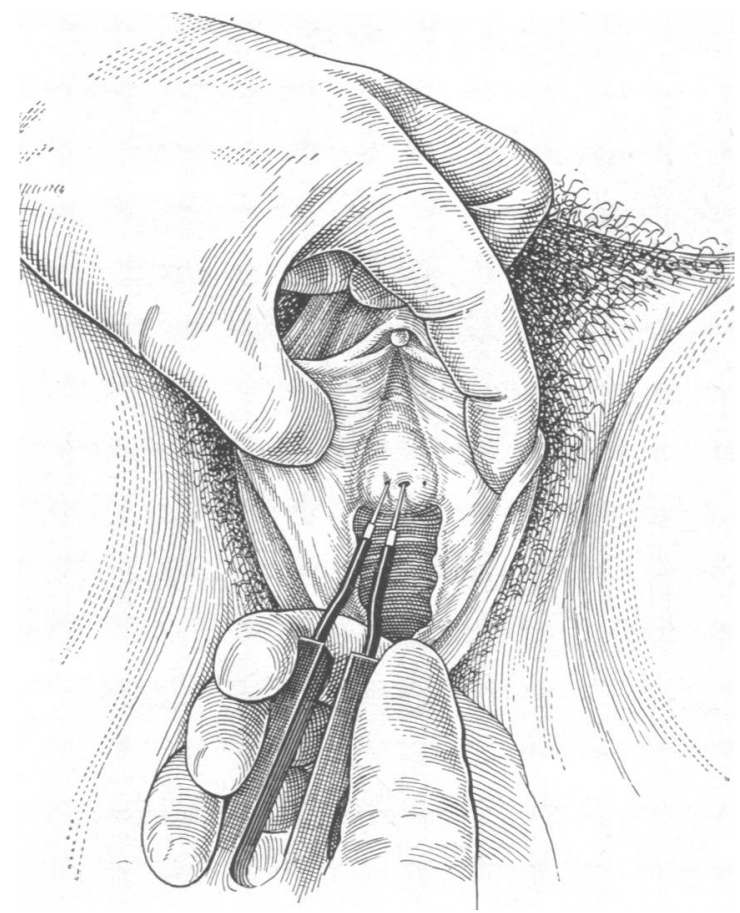

FIG. 6.-Opening up the gland in the urethra in a case of skenitis, with our electrode.

owe much of our knowledge of this subject. I should, however, like to describe three types of case.

(1) Male Cases with Obvious Symptoms.Treatment is relatively simple when the diagnosis has been established (chemical urethritis, bacterial urethritis, etc.) ; the same is true in dealing with the non-specific urethritis of Hecht or Waelsch and with abacterial pyuria and so-called Reiter's disease. The last-named is now (thanks to English workers) thought likely to be an infection by virus or L organisms, and it is hoped that aureomycin will prove effective.

Typical inclusion bodies have been found or cultures of $\mathrm{L}$ organisms obtained by us (Durel, Roiron-Ratner, Siboulet, and Borel, 1950) in cases of Waelsch's urethritis or the conjunctival-urethroarthritis syndrome. Of 106 male patients examined, seventeen were positive (three with Reiter's syn- 


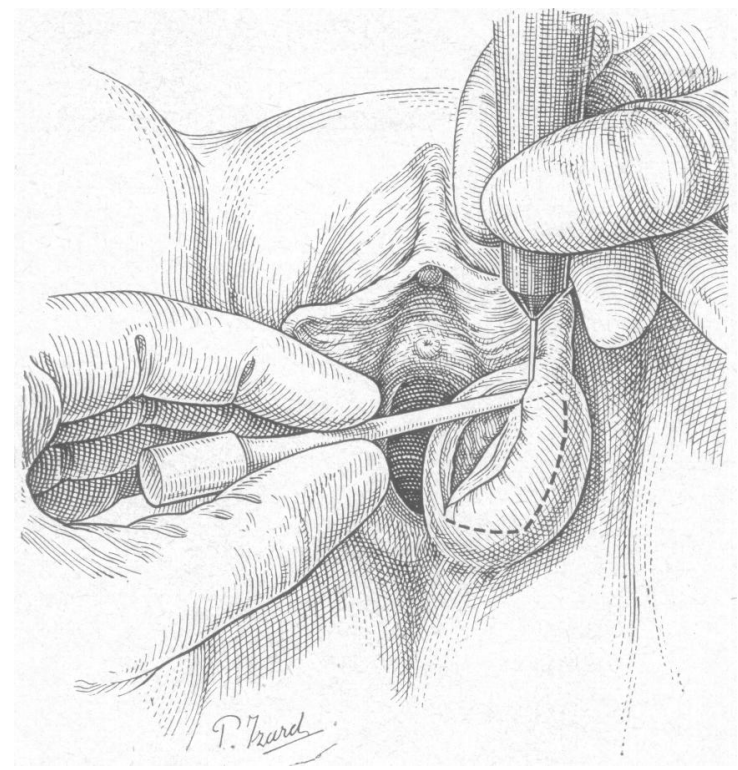

FIG. 7.-Case of bartholinitis. Incision with electric bistoury, using as guide bone stiletto (non-conductor).

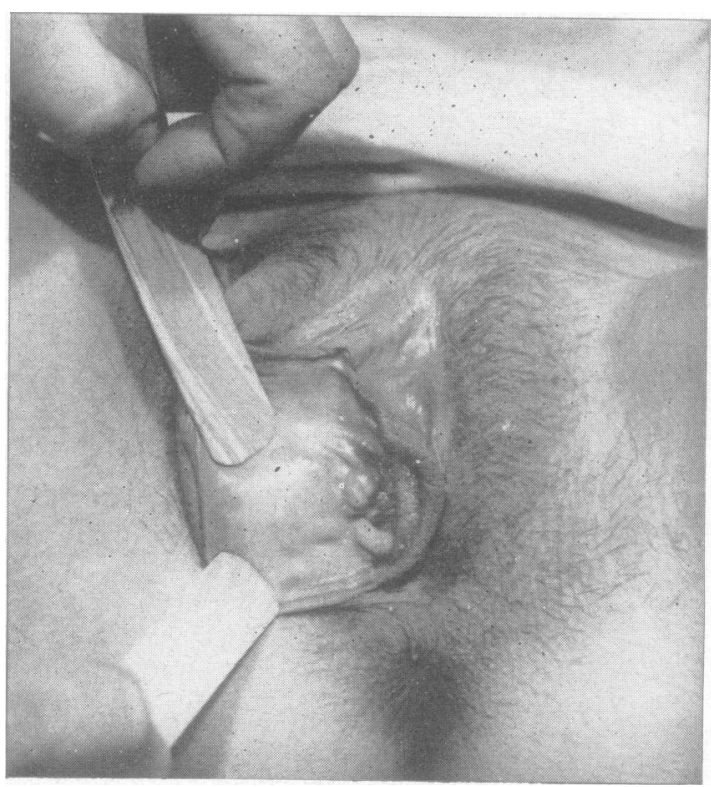

FIG. 8.-Laying open the gland in a case of bartholinitis. Result after one year.

disappointing; the patients who are clinically typical do not always show inclusion bodies, or a slide, because of artefacts, may be difficult to interpret. Cultures too cause difficulties, being negative in cases clinically typical and positive in healthy individuals (in our experience seven of these out of 35 examined).

Clinical Experiment.-Clinical experiment underlines the fundamental fact of the activity of aureomycin. At the Hôpital St. Lazare we have had excellent results, and-as in gonorrhoea-we try to treat infected couples at the same time. In spite of the small doses of aureomycin used ( $2 \mathrm{~g}$. daily for 3 days) we have noted in about 10 per cent. of patients oral or rectal incidents due doubtless to the action of the antibiotic on the flora of the alimentary tract. We have practically suppressed these by giving each day $100 \mathrm{mg}$. nicotinamide.

(2) "Morning Drip."-In our view this is rarely due to gonococci, but frequently to other bacteria and possibly, in rare cases, to an $\mathrm{L}$ organism or a virus. Micro-organisms may be present without being causative agents.

Hypospadias favours development of the condition, and we have very often found it is due to involvement of the prostate or vesicles.

French venereologists commonly use the following methods of treatment :

(i) An attempt is made to discover some focus by 
examination of the glans and palpation of the forepart of the urethra on Beniqué's sound, but it is often necessary to employ a urethroscope.

(ii) The patient is given Phenergan beforehand in order that he may have no reason to fear the examination (Durel, 1951).

(iii) When urethroscopy reveals nothing we have to be satisfied with " blind" treatment: massage of the urethra, prostate and vesicles, and lavage.

(iv) When these fail, aureomycin may be tried.

In France, as in other countries, in spite of all that we do we have resistant cases; these patients continue to report, and suffer from a kind of phobia because of indefinite early morning secretion. I try to allay their fears by explaining that, just as music-hall artists who have sung too much suffer from pharyngeal catarrh, so their urethra is irritated from over use, and that they should not be alarmed by such a secretion which, after all, is rather flattering !

(3) Female Cases.-A whole book could be written about non-gonococcal discharges in women. The urogenital tract provides a home for pyogenic organisms, fungi, trichomonads, viruses, etc. Endocrine over-activity may play a part, and the symptoms give little help in arriving at a diagnosis. In a field where so much confusion exists it is difficult to assess the value of what French workers have done.

Brumpt (1949) agrees with Bensen in saying that Trichomonas vaginalis is different from $T$. intestinalis. Varangot and Zaidman (1948) are more than pleased with the results they have obtained from a nitrofuraldehyde association in the treatment of trichomonal vaginitis. Martin (1950) is still pleased with douching with mepacrin solution. I myself have used aureomycin locally, the merits of which have been extolled by McVay and others (1949), but the patients have sometimes shown intolerance.

The subject of the sub-microscopic forms in women is an important one, especially as regards L organisms. In my Department, Mme Roiron, thanks to Bushby's penicillin-free medium, has made many successful cultures, but even more than in the case of men, the results were not in keeping with clinical findings.

In a series of 31 gynaecological cases, five positive cultures were obtained (cervix and urethra). The husbands of " positive" women were examined in three cases, in all of whom the urethra was dry and the husband reported no symptoms, but in one case the culture in the husband was positive also. In three cases urethral scrapings showed nothing.

In 161 prostitutes in whom there were no symptoms, we noted 32 positive $L$ cultures (cervix and urethra) and six of the cervix only.
In 51 prostitutes in whom the gonococcus was present, we noted 32 positive $L$ cultures (cervix and urethra) and four of the cervix only.

It would be difficult to understand these positive findings if one was not acquainted with the works of Klieneberger (1935), Dienes and others (1937-1950), Tulasne (1949, 1950), Warbasse and Johnson (1950), etc. They show that cultures of many bacteria on certain media, especially those containing penicillin, assume a resemblance to $\mathrm{L}$ organisms which morphologically are indistinguishable from those found in pleuro-pneumonia (PPLO).

We are dealing with stimulating findings, but we must use judgement in assuming that positive cultures denote a pathogenic agent. One understands why venereologists in every country-in Great Britain, Harkness, Edward, Bushby and others-are experimenting with selective culture media (leaving out penicillin), serological and cutaneous tests, experimental infections, and even with the electronic microscope. At the moment, going back to everyday practice, a positive culture is a suggestion that aureomycin may be effective.

\section{LEGISLATION}

Funds are obtained from two sources, the local government and the national government. In each department (corresponding roughly to an English county or county borough) there is a fulltime medical man in charge of administration; he has, to advise him, the senior venereologist in the area who is known as the Médecin Consultant de Vénéréologie, and these two are almost entirely responsible for the control of venereal disease in their area. Clinics, which were founded primarily to deal with syphilis only, now tend more and more to deal with all venereal diseases. The physicians in charge are qualified venereologists giving their services on a part-time basis. In the smaller towns where there is no venereologist and in others where patients are too numerous to be dealt with by the part-time services of venereologists, a wholetime venereologist is appointed by the Health Office. At the national level, in the Ministry of Public Health, there is a bureau dealing specially with venereal diseases, and liaison is assured by a Venereal Diseases Committee consisting of médecins consultants.

The following are the legislative enactments :

For the general run of patients the laws of December 31, 1942, and June 8, 1948, and for prostitutes the laws of April 13 and 24, 1946, and the regulations of November $5,1947$.

\section{Application of the Law}

A doctor is obliged by law to inform the patient of the nature of his disease, and the patient must undergo treatment. If the patient fails to do so, the doctor 
may report him to the Health Authorities who, in turn, can, after a social enquiry, have him compulsorily treated in hospital. For statistical purposes, venereal diseases must be notified without disclosing the patient's identity. Where, in the view of the doctor, the patient is a particular source of danger on account of occupation (cook, nurse, prostitute, etc.) the doctor is under an obligation to notify the patient's name and address to the Health Authorities, who can order admission to hospital. All persons are required by law to undergo a medical examination before marriage. Where a venereal disease has been diagnosed the doctor must tell the patient so, but the marriage of a contagious individual is not prohibited.

The two laws of April, 1946, have changed the official status of prostitution. The first marks the success of the abolitionists' campaign. Brothels have been closed and registration of prostitutes with the police has been abolished. It should be noted, however, that the brothels had come to have fewer and fewer visitors, and that prostitution as a whole was responsible for only some 35 per cent of venereal infections. An attempt has been made to determine whether the closing of the brothels has had any effect on reducing (or increasing) the incidence of venereal disease. No satisfactory answer can be found, for at the same time as the brothels were closed, penicillin was beginning to be widely used, and the increase in venereal disease due to the war was diminishing. (Cavaillon and Lavoine, 1950). My own view is that the brothels, few in number and poorly patronized, played a very small part in spreading venereal disease, and that from a public health point of view they could be ignored.

On the other hand, this first law of April, 1946, imposes heavy penalties on solicitation (up to five years' imprisonment and a fine of 10,000 fr.). On account of this severity, an accusation of soliciting is seldom made, and that particular clause of the Act has misfired and will have to be altered. The second law of April, 1946, has been regarded as something of a return to the old state of affairs. It establishes the Prostitution Sanitary File. When a woman is charged with prostitution (after a police round-up) she is given a medical examination, kept under observation by the Social Service (the police do not act directly), and obliged to report regularly at an approved clinic for medical examination (just as a benzole worker has to submit to blood examinations).

The law specifies that there should be a clinical examination twice a week, a laboratory examination once a week, and a serological examination once a month. As a matter of fact, in Paris, all that is required is a weekly clinical examination, a monthly culture test, and a serological control every three months. By means of the File we can ensure that examinations are being made and treatment regularly carried out. The File allows the general provisions of the laws of 1942 and 1948 (applicable to everyone) to be more easily applied to a special group of exposed and dangerous persons, and more particularly, the provision that a patient suspected of venereal infection must undergo medical examination and treatment where found necessary.
Nevertheless, some critics regard the File as of little value because it deals with only one group of possibly contagious individuals (but is such a group negligible and how would it be possible to get at the other contacts short of employing an army of social workers ?), or because it is unfair to women who might be prepared to undergo medical supervision voluntarily.

This last point is of interest for it is our obvious objective and we wish we could arrive at it by educative methods. Nevertheless, we have some evidence of what happened in the two years following the passing of the law, when the old form of organization was abolished. In those two years a few prostitutes did volunteer to be kept under regular medical supervision, but these were only a small minority. However, it is this cooperation at which we must aim ; in the meantime we use the File for want of something better. Let us hope that the time will come when those who expose themselves to infection will report for periodic medical examinations of their own accord.

\section{REFERENCES}

Aiken, R. B. (1949). J. vener. Dis. Inform., 30, 107. Baudouin, A., and Lereboullet, J. (1950). Proph. antivénér., 22, 428.

Bensen, - Cited by Brumpt (1949).

Berthoud, P. (1939). Ann. Mal. vénér., 34, 449.

Bilger, F., Zimmer, A., and Lachowiecki, J. (1938). Progr. méd., Paris, 66, 9.

Bolgert, M., and Levy, G. (1951). Médecine, 32, 18.

$\ldots, \ldots$, and Aladenise, J. (1949a). Bull. Soc. franc. Derm. Syph., 56, 58.

_- - - , and Desvignes, P. (1949b). Ibid., 56, 498.

,,,---- and Caramanian, M. (1950a). Ibid., $57,164$.

——, ——, —, - (1950b). . Ibid., 57, 308.

Paris, 66, 1131 .

(1950c). Bull. Soc. méd. Hôp.

P-, and Fauré, C. (1947). Bull. Soc. franç.

Derm. Syph., 8 sér., 7, 413.

Brumpt, E. (1949). " Précis de Parasitologie", 6th ed. vol. 1, p. 356. Masson, Paris.

Bureau, Y., Jarry, -., and Barrière, -. (1949). Bull. Soc. franc. Derm. Syph., 56, 453.

Burnier, L. (1946). Ibid., 8 sér., 6, 280.

Casabianca, J. (1947). Ibid., 8 sér., 7, 333.

Cavaillon, A., and Lavoine, R. (1950). Proph. antivénér., 22, 265.

Charpy, J. (1950). Inaugural Rep. Marseilles Branch Soc. franç. Derm. Syph.

Cooper, K. E., Mayr-Harting, A., and McLachlan, A. E. W. (1950). British Journal of Venereal Diseases, 26, 16.

Coste, F., Boyer, J., and Nehlil, J. (1946). Bull. Soc. franç. Derm. Syph., 8 sér., 6, 524.

$\longrightarrow$, Laurent, F., and Lapresle, J. (1948). Ibid., 55, 109. Darget, -., Muret, -., Dax, -., Ballanger, -., and Chabbert, - (1947). Bordeaux chir., p. 165.

Debré, R. (1949). Sem. Hôp. Paris, 25, 357.

Degos, R. (1943). Bull. Soc. méd. Hôp. Paris., 59, 229. , and Garnier, G. (1949). 7e Congr. Derm. Syph. Bruxelles, p. 133. Abstr. Pr. méd., 57, 748.

- Lortat-Jacob, E., and Maury, P. (1947). Bull. Soc. franç. Derm. Syph., 8 sér., 7, 351.

-, Vissian, L., and Basset, H. (1950). Ibid., 57, 209. Demanche, P., Durel, P., Ratner, V., and Collart, P. (1941). Bull. méd., Paris, 55, 533. 
Dienes, L. (1945). J. Bact., 50, 441.

-_, and Edsall, G. (1937). Proc. Soc. exp. Biol., N. Y., 36, 740 .

- , Ropes, M. W., Smith, W. E.. Madoff, S., and Bauer, W. (1948). New Engl. J. Med., 238, 509.

-, Weinberger, H. J., and Madoff, S. (1950). J. Bact., 59, 755 .

Durel, P. (1948a). “Les Métrites du Col”, 2nd ed. Masson, Paris.

_-(1948b). J. Prat., Paris, 62, 288, 295.

_- (1950a). “La Blennorragie." Masson, Paris. (1950b). Union int. Péril vénér., Zurich. (In the press.) (1950c). Gynéc. prat., 1, 105.

(1950d). J. Urol. méd. chir., 56, 540.

, and Daguet, G. (1949a). Bull. Soc. franç. Derm. Syph., 56, 452.

__-(1949b). Proph. antivénér., 21, 431.

- , and Dubost, P. (1945). Bull. Soc. méd. Hôp., Paris, 61, 193.

-_, Ratner, V., and Siboulet, A. (1947). Bull. Soc. franç. Derm. Syph., 8 sér., 7, 22.

__ Rayroux, J., Siboulet, A., and Daguet, G. (1948). Ibid., 55, 152.

, 一 - - - - (1949). 7e Congr. Derm. Syph., Bruxelles, p. 88. Abstr. Pr. méd., 57, 748.

-, Roiron-Ratner, V., Siboulet, A., and Borel, L. J. (1950). Sem. Hôp. Paris, 26, 3386.

_- Sausse, A., Collart, P., Roiron, V., and Borel, L. J. (1951a). Bull. Soc. franç. Derm. Syph., 58, 23. 23, 59 . - - - - - - (1951b). Proph. antivénér.,

Edward, D. G. ff. (1950). J. gen. Microbiol., 4, 311.

Fernet, P., and Guibert, J. (1946). Bull. Soc. franç. Derm. Syph., 8 sér., 6, 280.

Fournier, A. (1873). "'Leçons sur la Syphilis,” p. 1015. Delahaye, Paris.

Gaté, J., and Cuilleret, P. (1947). Ibid., 8 sér., 7, 293. —_, and Pellerat, J. (1949). 7e Congr. Darm. Syph., Bruxelles, p. 127. Abstr. Pr. méd., 57, 748.

Gougerot, H. (1950). Bull. Acad. nat. Méd., Paris, 134, 144.

- Civatte, A., and Meyer, J. J. (1948). Bull. Soc. franç. Derm. Syph., 55, 264.

_-, and Degos, R. (1950). Proph. antivénér., 22, 389. -, Meyer, J. J., Schneider, J., and Vissian, L. (1948). Bull. Soc. franç. Derm. Syph., 55, 16.

Grover, R. W. (1948). Amer. J. Syph., 32, 461.

de Graciansky, P., Boulle, S., and Hardouin, J. P. (1950). Bull. Soc. franç. Derm. Syph., 57, 317.

Harkness, A. H. (1949). Proph. antivénér., 21, 624.

-(1950). "Non-gonococcal Urethritis." Livingstone, Edinburgh.

Horne, G. O. (1950). British Journal of Venereal Diseases, 26, 23.

Huriez, C., Baelden, J., and Dusausoy, R. (1950a). Bull. Soc. franç. Derm. Syph., 57, 515.

-,$-\ldots$, - (1950b). Pr. méd. , 58, 1500.

- , and Desurmont, M. (1947). Bull. Soc. franç. Derm. Syph., 8 sér., 7, 343.

_- Merville, R., Baelden, J., and Soufflet, C. (1949). Pr. méd., 57, 389.

Joulia, P. (1950). Comptes-rendus, Journées Nat. Prophyl. antivénér. (Clinique Dermatologique de Bordeaux), p. 82.

Klieneberger, E. (1935). J. Path. Bact., 40, 93.

Klieneberger-Nobel, E. (1945). Lancet, 2, 46.

Kolmer, J. A., and Rule, A. M. (1947). Arch. Derm. Syph., 56, 179.

$\longrightarrow$ - (1948). Ibid., 57, 965.

Lamy, M. (1950). Union int. Péril vénér., Zurich. (In the press.)
Lamy, M., Jammet, M. L., Aussannaire, M., and Labesse, J. (1949). Sem. Hôp. Paris, 25, 2344.

Levaditi, C. (1928). Bull. Soc. franç. Derm. Syph., 35, $28,587$.

_130, 284.

1_, (1950). Pr. méd., 58, 1397.

Magnuson, H. J., and Thompson, F. A. (1949). J. vener. Dis. Inform., 30, 309.

Martin, J. Purdon (1948). British Journal of Venereal Diseases, 24, 89.

Martin, P. (1950). C.R. Soc. franç. Gynéc., 20, 63.

Maupin, B., and de Lestrade, B. (1950). Proph. antivénér., 22, 41.

McVay, L. V., Laird, R. L., Flanagan, J. B., and Sprunt, D. H. (1949). Proc. Soc. exp. Bio., N.Y., 72, 674.

Merklen, F. P., and Baudu, L. (1948). Bull. Soc. franc. Derm. Syph., 55, 300.

—_, and Nezelof, C. (1947). Paris méd., 37, 119.

- Voisin, J., Rogé, J., and Cottenot, F. (1950) Bull. Soc. franc., Derm. Syph., 57, 508.

Moore, J. Earle (1948). British Journal of Venereal Diseases, 24, 1.

Nelson, R. A., and Mayer, M. M. (1949). J. exp. Med., 89, 369.

- - Zheutlin, H. E. C., Diesendruck, J. A.. and Austin, P. G. M. (1950). Amer. J. Syph., 34, 101.

Nicol, C. S. (1948). British Journal of Venereal Diseases, 24, 27.

Pagès, F., and Capdeville, J. (1950). Bull. Soc. franç. Derm. Syph., 57, 576.

Pätiälä, R. (1946). Acta Derm.-Venereul., Stockh., 26, 557.

Pellerat, J., and Cotte, J. (1948). Bull. Soc. franç. Derm. Syph.. 55, 313.

Périn, L., and Senghor, J. (1949). Ibid., 56, 499.

Plotke, F., Rodriquez, J., and Schwemlein, G. X. (1950). Amer. J. Syph., 34, 425.

Schwob, A., Bonduelle, M., and Vernant, -. (1948). Bull. Soc. méd. Hôp. Paris, 64, 687.

Sézary, A., and Galmiche, P. (1945). Bull. Soc. franc. Derm. Syph., 5, 315.

Simon, C. (1948). Ibid., 55, 140.

Sonnenberg, E. (1935a). Proph. antivénér., 7, 734. -(1935b). Przegl. Derm., 30, 244.

Thomas, E. W., Rein, C. R., Lancy, S., and Kitchen, D. K. (1950). Amer. J. Syph., 34, 331.

Touraine, A. (1947). Bull. Soc. franç. Derm. Syph., 8 sér., 7, 116, 338.

_-(1948). Ibid., 55, 272.

_-, Golé, L., and Etienne, M. (1948). Ibid., 55, 271. -_, _- Robert, -., and Foucquier, M. (1947a). Ibid., 8 sér., 7, 20.

$-\ldots,-$ Foucquier: M., and Benon-Robert, (1947b). Ibid., 8 sér., 7, 178.

_- Guex, -., Balter, -., and Carreaud, _. (1947c). Ibid., 8 sér., $7,453$.

Tulasne, R. (1949). Bull. Acad. Méd., Paris, 133, 409. (1950). C.R. Soc. Biol., 144, 1200.

Turner, T. B. (1948). J. Soc. Hyg., 34, 205.

Vaisman, A. (1949). Proph. antivénér., 21, 160.

Vanhaecke, E. (1944). Echo méd. Nord., 15, 236.

Varangot, J., and Zaidman, H. (1948). Sem. Hôp. Paris, 24, 1805.

Warbasse, W. W., and Johnson, F. H. (1950). J. Bact. 60, 279.

W.H.O. (1950). Techn. Rep. Ser., no. 15, p. 9.

Wilkinson, A. E. (1949). British Journa! of Venereal Diseases, 25, 9.

Willcox, R. R. (1950). Bull. Hyg., Lond., 25, 331.

_-, and Findlay, G. M. (1949). Brit. med. J., 2, 257. 